\title{
Canada commits money for human genome research
}

Quebec. The Canadian government has decided to spend $\mathrm{C} \$ 22$ million (US\$18 million) over the next five years on research to map and sequence the human genome.

Speaking at an international industrial biotechnology conference in Montreal on 2 June, Science Minister William Winegard and Health Minister Benoit Bouchard said C\$17 million will come from the federal government - C $\$ 12$ million of it from the Industry, Science and Technology Canada department (ISTC) and C\$5 million from the Medical Research Council of Canada (MRC). The remainder will come from the private National Cancer Institute of Canada (NCIC). The ISTC contribution is new money, while MRC's and NCIC's will come from their current budgets. NCIC's budget is derived from public donations to the Canadian Cancer Society.

The announcement is a victory for a group of prominent biomedical scientists who have tried to persuade the Canadian government to invest in such a project. "Four years ago we got a nice reception from the minister [Winegard], who was very sympathetic, but we were told there wasn't any money", said Louis Siminovitch, a medical geneticist who is director of the Samuel Lunenfeld Research Institute of Toronto's Mount Sinai Hospital.

Asked what might have changed the government's mind, Henry Friesen, MRC's new president, said he thinks that officials decided that it would be a mistake not to take part in the programme. "Maybe the case wasn't made as strongly in the past", he said. "There still is in some quarters a scepticism whether spending on this scale is justified. The resources here are relatively modest. But I think there's also growing recognition of what we're going to learn, and that it may cost us a lot more if we're not part of the club."

US genome officials are pleased that their northern neighbour is investing in research on the human genome. "We're very much looking forward to collaborating with Canada. It sounds very encouraging", says Elke Jordon, deputy director of the Office of Human Genome Research at the US National Institutes of Health (NIH). "We have been expecting this for some time, but I know there were delays."

The Canadian prime minister, Brian Mulroney, has been willing to provide money for projects in which the private sector shares the cost. Friesen's new long-term strategic plan for MRC emphasizes partnerships (see Nature 357, 271; 1992), and in talks with government officials before his appointment Friesen used the genome project as a case in point. The Pharmaceutical Manufac- turers' Association of Canada has also expressed an interest in the genome effort.

ISTC's contribution to the project, and the fact that it was announced at an industrial conference, suggests that the government sees the genome project as economically profitable. "This is the kind of investment that governments must undertake in partnership with the stakeholder [and that] contributes to ... competitiveness and to our nation's long-term prosperity", says Winegard, who referred to applications "ranging from health care to agriculture, industrial biotechnology, environmental remediation, forestry and informatics".

NCIC's unsolicited contribution of $\mathrm{C} \$ 5$ million to the genome project is a reflection of the important role that genes play in cancer research. "This was the hot new topic that fired everyone's imagination", says Friesen, a former NCIC president.

The kinds of research to be carried out and the balance between biology and technology will be decided by a management team headed by Ronald Worton, professor of medical genetics at the University of Toronto and geneticist-in-chief at the Hospital for Sick Children. Worton directed research that led to the identification and characterization of the gene responsible for Duchenne muscular dystrophy.

$\mathrm{He}$ is also one of 11 Canadian members of the international Human Genome Organization (HUGO) and a member of the advisory committee that made recommendations to Canada's three research fundgranting councils on the formation of the Canadian programme. These are the MRC, the Natural Sciences and Engineering Research Council (NSERC) and the Social Sciences and Humanities Research Council (SSHRC). Together with ISTC and NCIC, they make up the genome programme management committee.

Friesen thinks that the project will fund both research proposed by the advisory committee and investigator-initiated proposals. $\mathrm{He}$ guesses that the latter "would be the dominant activity". He expects that both the human genome and model species will be explored. "There's considerable strength in mouse genetics and yeast genetics in Canada", he says.

The genome project should also stimulate the development of new technology, possibly in collaboration with industry. The project will provide money for training programmes, in particular for postdoctoral fellows, and 7.5 per cent of its funds will be devoted to the social, ethical and legal issues of genetic research. The first round of grants will be awarded in late autumn after a review in September.

\section{Industry surprised by firm US stance on biodiversity treaty}

Washington. When US President George Bush flatly refused last week to negotiate a biodiversity treaty at the Earth Summit because of what he saw as an unacceptable tradeoff between biological diversity and US jobs, he disappointed environmentalists and made headlines. He also surprised the very industry he was claiming to defend.

Officials at two major biotechnology associations say they do not oppose the gist of the treaty. Their concerns, expressed in letters to the White House, focused on draft language that could set a precedent for government control over industry licensing and technology transfer practices. But they had hoped that the offending language could be modified rather than made moot by the president's unyielding stance.

Bush refused to negotiate, however, and even rejected an appeal by William Reilly, head of the US Environmental Protection Agency, to consider compromise language suggested by the Brazilians. "I have to be the one ... responsible for jobs," Bush told reporters last week. "I have nothing to be apologetic for."

Contrary to the impression left by Bush, the biotechnology industry was not wringing its hands over the proposed treaty. On 18 May, the Association of Biotechnology Companies (ABC) wrote a letter to Bush devoted largely to its support of a controversial gene patent application by the National Institutes of Health. It attached an eightpage position paper on the subject. $A B C$ also said in the letter that it would oppose "any provision that would eliminate or dilute the protection of intellectual property rights for biotechnology ... or would require or permit national legislation compelling the transfer of technology". The accompanying position paper was two paragraphs.

William Sweet, president of the ABC, says he was "kind of surprised" by the strong US response. The Industrial Biotechnology Association (IBA) held a meeting with White House officials in what Lisa Rains, IBA's vice president for government relations, calls a "low-keyed lobbying effort" to modify the proposed treaty.

Pharmaceutical companies, another group likely to be affected by the intellectual property provisions of the treaty, were caught offguard by the US position. The Pharmaceutical Manufacturers Association did not even discuss the treaty until this week, according to a spokesman. "It's puzzling that a number of other nations with a substantial interest in the technology have somehow made themselves comfortable enough to sign the treaty", says James Russo, director of government and public policy for Smith-Kline Beecham.

Christopher Anderson 